\title{
We Shall Win: Yugoslav Film Cooperation with FRELIMO
}

We Shall Win (Venceremos): a cooperação cinematográfica jugoslava com a FRELIMO

We Shall Win (Nous vaincrons): coopération cinématographique yougoslave avec le FRELIMO

\section{Radina Vučetić}

\section{OpenEdition}

\section{Journals}

Electronic version

URL: http://journals.openedition.org/rccs/8652

DOI: $10.4000 /$ rccs. 8652

ISSN: 2182-7435

Publisher

Centro de Estudos Sociais da Universidade de Coimbra

Printed version

Date of publication: 1 May 2019

Number of pages: 131-150

ISSN: 0254-1106

\section{Electronic reference}

Radina Vučetić, «We Shall Win: Yugoslav Film Cooperation with FRELIMO », Revista Crítica de Ciências Sociais [Online], 118 | 2019, Online since 26 April 2019, connection on 19 March 2020. URL : http:// journals.openedition.org/rccs/8652 ; DOI : https://doi.org/10.4000/rccs.8652 


\section{RADINA VUČETIĆ}

\section{We Shall Win: \\ Yugoslav Film Cooperation with FRELIMO}

This paper deals with Yugoslav-Mozambican film cooperation and the role Filmske novosti played in the anti-colonial struggle and in the relationship with the FRELIMO movement in particular. Yugoslav film cooperation with Africa began in the 1950 s and peaked in the 1960s, when the Yugoslav Film Weeks were organized in the newly liberated African countries and Filmske novosti made their first documentaries in Algeria, Mali, Tanzania, Guinea and Mozambique. Film cooperation with Algeria and Mozambique and the support for such guerrilla movements as the FLN and FRELIMO was the climax of Yugoslav film solidarity with the anti-colonial struggle. The Yugoslav film We Shall Win (Venceremos), by Dragutin Popović, had an especially relevant role as the first documentary about the liberated regions in Mozambique and the military and political role of FRELIMO.

Keywords: anti-colonialism; FRELIMO; liberation movements; Mozambique; newsreels; Yugoslavia.

\section{Introduction}

In the process of decolonization, culture played a major role, with particular importance being attached to film. As soon as the colonial authorities became aware of the power of film and its influence on the masses, they began to use it as one more weapon to reinforce their domination. In these films the local populations were represented as inferior to their colonizers, thus justifying the existing colonial political and social hierarchy (Diop, 1980/1981: 27). However, as African liberation movements and organizations started to mushroom all over the continent and the decolonization process accelerated, film in Africa quickly followed the template, switching to the "liberation" narrative that focused on African national identities and internationalism and giving rise to Third Cinema. It was in this context that the liberation movements sought support in their struggle for autonomous status as nations and for an autonomous cinema. 
This paper aims to illustrate the role of documentaries produced by the Yugoslav film company Filmske novosti ${ }^{1}$ in Mozambique's national liberation and anti-colonial struggle. Due to its independent position between East and West and its status as one of the leaders of the Non-Aligned Movement (NAM), Yugoslavia had been supplying African liberation movements with various kinds of assistance since the mid-1950s. According to Rubinstein (1970: 91), anti-colonialism had "become the Yugoslav credit card to the Third World". Since the early 1950s, Yugoslavia had "sided with the efforts of indigenous peoples to break the shackles of colonial rule", offering different kinds of support (ibidem). Yugoslavs were aware that this cooperation had to be based on universal political principles and mutual interests rather than on ideological identification or regional alliances (Dimić, 2017: 9). The Algerian War (1954-1962) and the Belgrade Non-Aligned Conference (1961) marked the first Yugoslav connections to the liberation movements. Almost 40 anti-colonial movements, mostly from Africa, took part in the Belgrade Summit (Bogetić and Dmić, 2013: 189-201). During the 1960s and 1970s, Yugoslavia offered the African liberation movements not only military aid, but also its political philosophy and its experience of national liberation in World War II. Various delegations were offered courses about the Yugoslav National liberation struggle, and Yugoslav partisan movies were sent to the liberated countries. ${ }^{2}$ According to the Yugoslav League of Communists' estimates, the greater part of this aid must have gone to the movements from the Portuguese colonies (People's Movement for the Liberation of Angola - MPLA, African Party for the Independence of Guinea and Cape Verde - PAIGC, Mozambique Liberation Front - FRELIMO). The assessment of the needs was based on their level of organization, their degree of "political awareness", their commitment to non-alignment and socialism, opportunities in the newly freed territories, and approval from the Organization of African Unity (OAU) as well as the United Nations (UN). ${ }^{3}$ The Yugoslav authorities even created the Fund for Assistance to Victims of Aggression and Colonial Domination, in order to coordinate aid to the liberation movements, predominantly in

\footnotetext{
${ }^{1}$ In most articles in English, Filmske novosti is not translated. The literal translation would be "Film News", but the term "the Yugoslav Newsreels" is used instead.

${ }^{2}$ Archives of Yugoslavia, KPR, II 3-b-2/24, Informacija Komisije za međunarodne veze o pomoći Jugoslavije oslobodilačkim pokretima i antikolonijalnim pokretima [Information from the Commission for International Relations on Yugoslavia's assistance to liberation and anti-colonial movements], 05.03.1964.

${ }^{3}$ Archives of Yugoslavia, KPR, II-3-b-2/57, Informacija o narodnooslobodilačkim pokretima Afrike i saradnji sa njima [Information on African people's liberation movements and cooperation with SSRNJ with them], 31.12.1969.
} 
Algeria, Western Sahara, Angola, Mozambique, Zimbabwe, South Africa, Namibia and Kenya (Radonjić, n.d.). This also meant that in several African countries fighting for independence, film cameras began to arrive alongside the weapons and to shoot almost as effectively.

The Filmske novosti collection includes various images of African and Asian liberation movements and revolutionary leaders, from the Algerian War to guerrilla actions of the FRELIMO to footage of the Palestine Liberation Organization (PLO) training camps, to mention some of the most significant. The main idea behind this was to create transnational networks of solidarity with the help of the film industry. My analysis is based on the case-study of what is called "Mozambican collection" of the Filmske novosti archive, compiled between 1967 and 1986 in close collaboration with Mozambique's FRELIMO movement, and particularly on the Yugoslav documentary We Shall Win (Venceremos) (1967), ${ }^{4}$ which was advertised and distributed by the Madison Area Committee on Southern Africa (MACSA) $)^{5}$ under the caption: "the first documentary about the liberated areas in Mozambique and the military/political role of FRELIMO. Filmed with FRELIMO in northern Mozambique". ${ }^{6}$

Most studies on international film support to FRELIMO tend to downplay Yugoslavia's contribution to Mozambique's early cinema, focusing on other countries and authors instead. An "eminent group of international filmmakers and activists from countries as diverse as France, Sweden, Yugoslavia, and Cuba" are thus usually mentioned as having made significant contributions to revolutionary cinema, and one finds references to the fact that authors like Jean Rouch, Jean-Luc Godard, Ruy Guerra and Robert Van Lierop are part of Mozambique's cinematic heritage (Andrade-Watkins, 1995: 135-137). Among the notable exceptions to such oversight are the March 2012 issue of the Journal of African Cinemas (volume 3, number 2), devoted to Mozambican cinema, and a few authors who studied the role of Yugoslavia in Mozambique's cinematic liberation war (Power, 2004; Gray, 2012; Schefer, 2013; Luque, 2017). Barring Jorge Carvalho’s work (2018), the studies and bibliography on Yugoslav-Mozambican and Yugoslav-Portuguese relations are almost non-existent.

\footnotetext{
${ }^{4}$ Pobedićemo/We Shall Win (1967), by Dragutin Popović. Filmske novosti.

5 Madison Area Committee on Southern Africa was a community-based organization of students, professors and faculty members at the University of Wisconsin-Madison, United States of America. It was formed in 1968 to lobby and educate the community about South Africa and to provide assistance to liberation movements.

${ }^{6}$ M.A.C.S.A. News, no. 19, Sept.-October, 1972. Accessed on 17.11.2018, at http://kora.matrix. msu.edu/files/50/304/32-130-175B-84-MACSA_News19_opt.pdf.
} 
My analysis of the We Shall Win documentary aims to start filling this gap in the existing literature. I will also analyze the ideological background, or indeed, the underlying political message of the documentary, against the backdrop of official Yugoslav policies of decolonization and solidarity within the then emerging NAM. My main argument is that this documentary, devoid as it was of any socialist ideology, greatly contributed to the internationalization of the anti-colonial struggle of African peoples, the creation of the Mozambican film industry, and eventually to the creation of a specific guerrilla film genre, which influenced many other liberation movements across the continent that ended up accepting the same or a similar strategy in their own struggle for independence.

\section{Filmske novosti Goes to War}

Filmmaking, both documentary and fiction, in support of rebel causes can be found all around the world, from Palestine to Latin America. A network of pro-liberation African cinema first came on the scene in the late 1960s (Gray, 2011: 140). It is no wonder that young members of guerrilla movements such as PAIGC's Flora Gomes and Sana Na N'hada were sent to Cuba to learn the language and techniques of Third Cinema, whose values of revolution and social justice echoed the early, utopian ideals of African anti-colonial struggles. As African movements attracted international solidarity, filmmakers swarmed to support them, both by making films and by training filmmakers (Sousa, 2016). Over the years, the number of foreign filmmakers in an array of African countries fighting for freedom increased steadily. Their films stood as visual testimony to the liberation movements' struggle to overthrow the colonial governments while being part of the effort to mobilize the international community. At the same time, these films became a powerful tool for newly proclaimed "national audiences" (Luque, 2017: 116). At the Meeting of Third World Filmmakers, held in Algiers in 1973, filmmakers who had been trained in the Soviet Union and in Cuba Ousmane Sembène, Flora Gomes, Sarah Maldoror and Sana Na N'Hada - discussed how a liberated African cinema might be built, based on the idea that, in the revolutionary war, "the only form of artistic expression is armed struggle: the absolute quest for independence" (Sembène apud Gray, 2012: 57). Their intention was to build production and distribution mechanisms that would serve the African Revolution (ibidem). The wars of independence in the former Portuguese colonies of Angola, Mozambique and Guinea-Bissau had their own film side to them. The MPLA, PAIGC and FRELIMO invited international filmmakers to follow their struggle for independence up close (Ferreira, 2011: 222). 
The importance of the media, primarily radio and film, had long been stressed in Yugoslav analyses vis-à-vis the Third World. These analyses not only confronted the West and Western influences, but also countered such "reactionary" socialist countries as China - which had also intensified its propaganda in Africa since the mid-fifties - or socialist "rivals" like the Soviet Union and Cuba. According to various Yugoslav analyses of film propaganda in Africa, the most active among them were China, the Soviet Union and the German Democratic Republic (GDR). These countries offered specialized assistance mainly by sending their film crews and experts to the African continent, building cinemas (mostly China), sending cinema on wheels (Soviet Union) or film laboratories (GDR), and receiving African film workers for training in their own countries, as was especially the case with the GDR (Vučetić, 2017a: 61). However, according to the Yugoslav Comission for International Cultural Relations, despite the abundance of help provided to African-based cinema by China, the Soviet Union and the GDR, "they prefer to receive, or to ask for, our help, although it is much more modest in scope. The reason for this lies certainly in today's political position of our country and its foreign policy, but also in the approach, friendly relations, speed and quality of services, and above all in the respect for national pride and the national sensitivity of each country" ${ }^{7}$

Based on the "Records on Film Cooperation with African countries" of the State Commission for Cultural Relations with Foreign Countries, one is able to infer the advantages Yugoslavia had over its socialist counterparts, which stretched far beyond its non-bloc and independent politics. Most notably, Yugoslav filmmakers and producers were very careful "not to emphasize our [Yugoslav] participation either through images or words, but to value national provenance in every film component, including language - Arabic, Bambara or Swahili”. ${ }^{8}$ According to Yugoslav sources, such approach was completely different from that of films made for the African market by China, the Soviet Union or the GDR. In the above-mentioned "Records", an example of a Soviet film about Mali is mentioned in which Mali's values and natural wealth are presented, but the "fraternal unselfish help of the Soviet Union" is overemphasized immediately thereafter. Hence, it is not surprising that Malian and Tanzanian references to film cooperation with Yugoslavia stress the fact that having the Yugoslavs

\footnotetext{
7 Archives of Yugoslavia, no. 559, Opšti materijali 1968, Elaborati o me unarodnim vezama nekih kulturnib i prosvetnih organizacija i institucija, maj 1968 [General materials 1968, Records on international relations of some cultural and educational organizations and institutions, May 1968]. ${ }^{8}$ See footnote no. 7.
} 
filming meant that, "for the first time, they got their true films". Algeria received the largest portion of Yugoslavia's assistance, but many sub-Saharan countries were also on the receiving end of this cooperation. Yugoslav documentary films and newsreels were of great importance in the processes of newly gained independence and contributed significantly to good cooperation with the newly liberated African countries as well as to the spreading of news of the anti-colonial struggle around the world.

Like other African liberation movements, FRELIMO saw the huge potential of film as a revolutionary tool to inform and mobilize the peoples of Mozambique. Since the foundation of its cinema department in 1966, FRELIMO encouraged the production of films to inform on national and international perspectives on the anti-colonial war and invited film-makers from around the world to illustrate the many aspects of their struggle against the Portuguese, particularly in the liberated territories (Power, 2004: 269; Bamba, 2011: 177). As far as Yugoslavia is concerned, the most important role in film co-operation with African countries and their liberation movements was played by Filmske novosti, which was under direct state control. Turajlić's study of Filmske novosti illustrates the role it played in mobilizing support for the NAM, in which Yugoslavia had a leading role, especially after hosting its inaugurating Summit in Belgrade in 1961 (Turajlić, 2017b). Because anti-colonialism was one of the cornerstones of Yugoslav foreign policy, Josip Broz Tito offered economic, technical and cultural assistance to the countries fighting for the anti-colonial cause. The founding of the NAM opened up new possibilities with regard to cooperation among and with Third World countries. Within the context of the establishment of diplomatic relations with the developing world, Tito showed a strong interest in the political and social affairs of African countries in particular (Vučetić, 2017b: 13). In terms of cooperation with the Third World, 1954 was a milestone year. That was when Filmske novosti was included in the program of the international film exchange of film newsreels, and cameramen Dragan Mitrović and Stevan Labudović travelled with Tito to India, Burma and Ethiopia (Turajlić, 2017a: 171). During the sixth, seventh and eighth decades of the $20^{\text {th }}$ century, Filmske novosti reached a significant level of cooperation with Algeria, Mali, Tanzania, Guinea, Congo-Brazzaville and Mozambique - namely with FRELIMO -, within the framework of international agreements of a scientific, technical and cultural nature. This cooperation lasted long enough to create an extensive archive as well as Filmske novosti school that was attended by future African cameramen

\footnotetext{
${ }^{9}$ See footnote no. 7 .
} 
and editors who in turn were later to establish national cinema in their own countries (Filmske novosti, 2014: 34-35).

As mentioned earlier, Yugoslav film cooperation with Algeria was the most important, and almost on a par with political cooperation. In this, Filmske novosti played a vital role. After the Provisional Government of the Algerian Republic (GPRA) was established, in September 1958, the number of diplomatic initiatives increased and a cooperation agreement was reached in June 1959, when Tito received a delegation from the Algerian government. It was then agreed to establish a film service within the GPRA, which would sign a contract with Filmske novosti to cover the Algerian struggle and sending a cameraman to the Algerian National Liberation Army, on the Algerian-Tunisian border (Turajlić, 2017a: 173). Tito sent Stevan Labudović, a young cameraman from Filmske novosti, to assist Algeria's freedom fighters. Labudović spent almost three years (between 1959 and 1962) with Algerian partisans, carrying a camera in one hand and a rifle in the other. His photographs and footage became invaluable witnesses of the struggle for independence. ${ }^{10}$ Even today, Stevan Labudovic is celebrated in Algeria as the "cinematic eye of the Algerian revolution"11 and his camera is on display at the National Museum. Thus, Filmske novosti created a large documentary collection about the Liberation War, which is now part of the Filmske novosti archives and constitutes rich visual testimony to the Algerian army and the liberation struggle from that time. ${ }^{12}$ Filming in the Algerian army continued with minor interruptions until June 1965, and in addition to documentary filming, at one time Filmske novosti had a whole team at the Supreme Headquarters, conducting two three-month training courses for military cameramen and photographers. Two teams of Filmske novosti filmmakers also recorded the entry of Algerian troops (stationed in the free territory) into Algeria, as well as the triumphal route of Ben Bella and other Algerian leaders across the country. Shortly after the liberation of Algeria several films were shot, as was the case, in 1963, with Proslava nacionalnog praznika (National Day Celebration) (Vučetić, 2017a: 70-72).

10 "Svedoci istorije: Stevan Labudović i borba za oslobođenje Alžira" [Eyewitnesses to History: Stevan Labudović and The Algerian War of Independence]. Accessed on 20.09.2017, at https:// politfilm.files.wordpress.com/2014/09/svedoci-istorije-stevan-labudovic-i-borba-za-oslobodjenje-alzira.pdf.

11 “The Labudović Reels", Institute of Documentary Film. Accessed on 21.10.2018, at https:// dokweb.net/database/films/synopsis/48749507-bd32-43db-baae-4bfcb4d96a26/the-labudovic-files. ${ }_{12}$ The collection consists of five Algerian film journals and newsreels and film documentaries, the most important of which are: Đazairouna (Djazairouna: Our Algeria), Za budućnost Alžira (For the Future of Algeria), Posle četrnaest godina (After 14 years), Dan nezavisnosti (Independence Day), Petnaestogodišnjica (15th Anniversary), Flammendes Algerien and Refugies algeroens (Filmske novosti, 2014: 37). 
In addition to this cooperation during the war for Algerian independence, which was the first and most important instance of its direct assistance to liberation movement, Filmske novosti played a significant role in Mozambique. The "Mozambican collection", created between 1967 and 1986, consists of the following documentary films: We Shall Win (1967), The Message of FRELIMO President to the People of Mozambique (1975), Nachingwea - the Revival Camp (1976), KOLOMBO - Anti-imperialist front (1977), $3^{\text {rd }}$ FRELIMO Congress (1977), First Anniversary of Independence (1977), and "other materials about Mozambique" (Filmske novosti 1944-2014, 2014: 39). Cooperation with the Mozambican freedom fighters started in Tanzania. During the filming of the Yugoslav newsreel about Tanzania, the Filmske novosti crew established contacts with the representatives of the FRELIMO movement who led the struggle for the liberation of Mozambique. ${ }^{13}$ After lengthy preparations, permission was granted for a Filmske novosti cameraman, Dragutin Popović, to enter the liberated territory of Mozambique. The result was the film We Shall Win. It was presented to the President of FRELIMO, Eduardo Mondlane, and Edvard Kardelj ${ }^{14}$ handed over a copy of it to the Vice-President of the Tanzanian Government upon his visit to Dar es Salaam. ${ }^{15}$

Several copies were made and dubbed into English, French and Portuguese, and there was a screening in Addis Ababa during the OAU session. It was a great opportunity for Yugoslavia to present itself as a significant film partner and to promote not only its film-related accomplishments, but also solidarity with the liberation movements and newly established African countries. On this occasion, FRELIMO leaders in Dar es Salaam said that this film "represents a great Yugoslav help in the liberation struggle of Mozambique" 16 and pointed out the fact that filmmaker Dragutin Popović, of Filmske novosti, was the only foreign journalist ever allowed into the freed territory, following in the footsteps of cameraman Stevan Labudović and his pioneering work in Algeria. The role of independent Yugoslavia proved to be important for Mozambique, as Mondlane clearly put it: "it is no coincidence that the first permission was given to a Yugoslav reporter, since the film made by the Yugoslav has more persuasiveness than the work of any cameraman of another nationality". ${ }^{17}$ This cooperation was also more markedly anti-colonial in character, as evinced by

\footnotetext{
${ }_{13}$ At that time, FRELIMO had its basis in Tanzania.

${ }^{14}$ At the time, Edvard Kardelj (1910-1970) was the President of the Federal Assembly of Yugoslavia.

${ }_{15}$ Archives of Yugoslavia, no. 559, Opšti materijali 1968, Elaborati o međunarodnim vezama nekih kulturnib i prosvetnih organizacija i institucija, maj 1968 [General materials 1968, Elaborates on international relations of some cultural and educational organizations and institutions, May 1968].

${ }_{16}$ See footnote no. 15.

17 See footnote no. 15.
} 
the fact that, after the presentation of the film in Addis Ababa, aid committees for Mozambique and anti-colonialist organizations from the Netherlands, Great Britain and the United States of America (US) asked Filmske novosti to sell the copies for the Week of the Fight against Colonialism. Although Yugoslav film companies and producers usually acted according to market principles, Filmske novosti waived the possibility of exploring the film commercially, on the grounds that "it is incompatible with the free screenings organized by the committees and anti-colonial organizations in many countries", and gave it away for free. ${ }^{18}$

Although Filmske novosti and the Yugoslav Film Museum date We Shall Winn from 1967, there is a slight confusion in foreign literature about the year the film was made. Power's research even dates it back to 1966 (Power, 2004: 270). Writing about the "guerrilla" genre, or liberation cinema in Mozambique and Angola, Andrade-Watkins begins with the year 1969 (Andrade-Watkins, 1995: 135-137), although We Shall Win and Dez dias com os guerrilheiros de Moçambique livre, produced by Franco Cigarini for Italian television, were both made two years before that (Power, 2004: 270). After these pioneering films, Robert F. Van Lierop, an African-American lawyer, activist and filmmaker, started his Mozambique Film Project. ${ }^{19}$ Its first film $A$ luta continua (The Struggle Continues), ${ }^{20}$ was about the liberation struggle in Mozambique. The film was the American version of more than 10 propaganda films made behind the front lines in Mozambique, between 1967 and 1973, by filmmakers from Yugoslavia, the Netherlands, China, Great Britain, the Soviet Union, Italy, Sweden, Algeria, the GDR and the US (Luque, 2017: 116). If we compare We Shall Win and A luta continua, the latter appears to have been greatly influenced by the Yugoslav film, which clearly served as its model (as discussed in more detail in the following pages). Therefore, although most of the cinema production about FRELIMO and the Mozambican struggle for independence alludes to the documentaries made in the early 1970s, We Shall Win clearly shows that Yugoslav film solidarity and cooperation with FRELIMO started much earlier. Moreover, the 1967 documentary illustrates the beginning of FRELIMO's anti-colonial struggle while also marking the beginning of the presentation of its struggle to an international audience through various film screenings and festivals.

\footnotetext{
18 See footnote no. 15 .

19 "Mozambique Film Project", African Activist Archive. Accessed on 16.11.2018, at http://africanactivist.msu.edu/organization.php?name=Mozambique+Film+Project.

${ }_{20}$ A luta continua (1971), by Robert van Lierop, California Newsreel. The film is available at https:// archive.org/details/alutacontinuathestrugglecontinues (accessed on 16.11.2018).
} 


\section{We Shall Win - Film Analysis}

FRELIMO was formed in 1962 under the presidency of Eduardo Mondlane, and already in September 1962 the movement had a conference in Dar es Salaam at which Mondlane urged his followers to "act, work and organize that we may free our continent from foreign oppression" (Arnold, 2018: 322). FRELIMO was quickly recognized by the OAU and started receiving funds from the organization. It also started getting financial and other kind of support from the Soviet bloc, China, Tanzania, Algeria, Egypt, Sweden and Denmark, as well as various international non-governmental organizations (NGOs). FRELIMO launched its fight against Portuguese colonialism on 25 September 1964 (ibidem: 323). Three years later, the Yugoslav documentary We Shall Win was made.

As mentioned in the opening scenes of the film, "this documentary was filmed on the liberated territory of Mozambique, near the town of Mueda, in the Cabo Delgado Province". This is followed by an introduction, both geographical and political, about the land and the people - "a land with about 100,000 Europeans and about 7 million Mozambicans" - and the circumstances in which they live: "this is a land of extreme deprivation, slavery oppression, this is their fatherland, which has been mercilessly exploited by Portugal's Salazar regime" and "only armed struggle", it is added, "can bring freedom to the people of Mozambique". Since armed struggle is viewed as the only option, the focus of the documentary is on the armed forces. In the Cabo Delgado Province, the Yugoslav newsreel reporter met Commander Samora Machel, ${ }^{21}$ who was "on the liberated territory for the first time". His guerrilla fighters are seen saluting their commander-in-chief, who makes three appearances in We Shall Win. No one else stands out among the masses of soldiers and the people of Mozambique, which means that, in fact, this documentary portrays him as the leader.

Further on, the narrator says (commenting on images of the armed forces) that the fighters are armed with "modern weapons, which they have received from friends or seized from the enemy". The weapons that can be recognized in the We Shall Win documentary are mostly Soviet: the majority of fighters are armed with Kalashnikov rifles, but one can also see a Soviet rocket launcher, a Soviet 82-millimeter mortar, a Soviet Shpagin

\footnotetext{
${ }^{21}$ Samora Machel was a FRELIMO military commander and the first President of Mozambique (1975-1986). When Machel emerged as an efficient field commander of the freedom fighters, in 1966, he had Mondlane's backing. When Mondlane was assassinated in Dar-es-Salaam in 1969, Machel succeeded him. Compared to the learned Mondlane with his international credentials, Machel, who had worked as a male nurse, had a very humble background, but he was an intelligent and highly successful guerrilla fighter (Rothermund, 2006: 231).
} 
submachine gun, and even a soldier wearing a ushanka fur cap (Petrović, 1981: 40; Ljubojević and Bogdanović, 2011: 202). The purpose of showing various types of modern weapons is not just to exhibit FRELIMO's military equipment, but to signal the level of modernization of its army.

These details from the film are very similar to the ideas underlying documentary films shot in Algeria, suggesting a calculated propagandistic intent on the part of Yugoslavia. This is corroborated by Zdravko Pečar's film script for one of the documentaries about Algeria. Pečar was a journalist, editor of the prominent daily newspaper Politika and the journal Medunarodna politika (International Politics) and, at the end of his career, the director of the Non-Aligned Radio Yugoslavia. From the early 1950s he was a correspondent in Cairo (since 1952) and Algeria. While in Algeria he fought in the FLN (National Liberation Front) and played an important role in promoting the Algerian struggle in Yugoslavia and throughout Europe. A firm anti-colonial discourse, the disregard for established colonial borders and the support for and advocacy of the liberation of African peoples were a constant and prominent feature of his writing, work and opinions (Radonjić, 2017: 164). In the above-mentioned script, written for Stevan Labudović and Filmske novosti, Pečar gave precise indications of what to record and how. The main objective set to the cameramen by Pečar's script was to portray the Algerian army as a "modern army", with an emphasis on footage of "automatic weapons", "battalions" and other attributes of regular armies. ${ }^{22}$ Numerous motifs presented in Pečar's film script about the Algerian War and the Algerian Army were also present almost ten years later in the film about FRELIMO. His suggestion that the young people who made up the majority of the troops should be the main focus also has a place in We Shall Win, as has the recurrent notion that special attention should be paid to automatic weapons and weapons seized from the enemy.

But We Shall Win also shows native Mozambicans wielding spears, bows and arrows, "the traditional weapons of this continent" (as stated in the documentary). This was meant to emphasize the readiness of the entire population to participate in the liberation struggle, for those with the traditional weapons, without proper uniforms and often barefoot were also part of the army units. Such scenes also served to highlight the rich cultural heritage of Mozambicans. In order to show that the whole population was involved in the liberation struggle, women in uniform are seen among the armed men (at some point in the documentary, cameraman Popović looks surprised to

${ }_{22}$ Archive of the Museum of African Art, K-42, Scenario i uputstvo za snimanje dokumentarnog filma o Alžiru [Scenario and instructions for documentary film about Algeria], Beograd, 18 July 1958. 
see an all-female unit), and children with military training are also pointed out ("army training is a compulsory subject in school, in addition to the regular curriculum"). Exceptional emphasis is given to the participation of young people in the army, carrying out various activities or attending the FRELIMO congress. They are described as "enthusiastic" and filled with a spirit of "devotion and readiness". This too was very similar to the already established model of documentaries made by Filmske novosti about the fighting in Algeria. Thus, Pečar's script also highlights the importance of the full support of the people to the Algerian army. ${ }^{23}$ The people's proximity and unity with the liberation army are stressed throughout the film. Small gifts from the local populations to the army are presented as "gratitude of the people from the liberated territories to those who had the courage to start the struggle and lead it".

Also intended by this film is to show that a new life in the liberated areas had begun, that the people themselves managed to till their land, started to produce things and worked for a living ("The new life must be organized in the liberated territory - a finer and better one than under colonial rule"). In addition to the army sequences, the songs, dances and day-to-day life of the Mozambican people can be seen as well. Children in schools, learning how to read and write, are also shown, along with the narrator's message that both "the mind and national awareness must be strengthened". The main purpose of We Shall Win, like almost all films about the liberation struggle in Mozambique, is to celebrate the building of a new society by depicting the military training, medical care and education efforts carried out in the liberated zones (Gray, 2011: 143).

The people of Mozambique are portrayed in contrast to the usual colonial stereotypes with their insistence on African laziness and backwardness. Thus, in many scenes they are shown growing and selling agricultural products or weaving traditional fabrics for themselves instead of doing it for the colonizers. A new life is also depicted through symbols - at one point in the narrative, the first flag of independent Mozambique and the first flag of FRELIMO are hoisted. As explained in the film, the hoisting of the flag was just the beginning of this "small daily ceremony": the day proceeds with a political address in which a member of the central committee speaks to the soldiers (both male and female) about successes achieved and difficulties felt, but also about freedom and "the need to regain their self-respect and dignity as Africans". During this ceremony we can hear Samora Machel

${ }_{23}$ Archive of the Museum of African Art, K-42, Scenario i uputstvo za snimanje dokumentarnog filma o Alžiru [Scenario and instructions for documentary film about Algeria], Beograd, 18 July 1958. 
declaring that "Mozambicans wish to be free as they once were, and more than that, they wish to join the free peoples of Africa and take part in the forming of a united free Africa, in a free peace-loving world". This is in line with Reno's writing that "Anti-colonial rebel success required showing outsiders a credible capability to control territory and administer communities" (Reno, 2011: 40), which is something that We Shall Win made internationally visible through world-wide screenings.

As already mentioned, liberated African nations, or those in the process of being liberated, sought Yugoslav help through documentaries because Yugoslavia did not overplay its role in the events filmed. Only at one point in the film can we see cameraman Dragutin Popović and the "Filmske novosti Beograd" logo on his camera, but that is the only hint at who was behind the shooting of this documentary. Even more striking is the fact that there is no display of socialist ideology in it. There is no mention of Marxism, socialism, capitalism; the only issue that is reiterated is colonialism, or rather, the anti-colonial struggle. There are suggestions of Yugoslav non-aligned policy, as there are of the political circumstances of the time. In 1967, when the film was made, FRELIMO still did not have a clearly defined ideological (Marxist) foundation, and received support from different parts of an ideologically polarized world. Although the bulk of FRELIMO's support came from socialist countries, notably China and the Soviet Union, in 1966 Sweden became the first Western country to give aid to FRELIMO, soon followed by other Scandinavian countries (Schneidman, 1978: 59-60). FRELIMO also had strong secret links to the US, and although Mondlane was a dedicated socialist, he believed that a broad united front would be the best for the cause of liberation, both domestically and internationally (Westad, 2005: 210). Therefore, with the OAU and the UN as the most prominent international organizations providing support to FRELIMO, Yugoslavia's non-aligned and anti-colonial stand was of great importance in bringing FRELIMO's armed struggle to the international arena. By avoiding socialist rhetoric, Yugoslavia thus became a key-player in building a global network of anti-colonial solidarity with the Third World.

This absence of socialist ideology in We Shall Win differed significantly from the situation in Algeria, as Pečars's instructions for filming a documentary clearly stated that the Algerian case involved a liberation movement that was also socialist in nature. This also differed sharply from the film A luta continua, in which the socialist revolution is granted as much significance as the anti-colonialist one. The leitmotif of We Shall Win is simply the anti-colonial struggle, with the theme of "colonial slavery" being mentioned several times. This was in accordance with Yugoslav policy, which tried to 
strike a balanced position not just in Africa but throughout the Cold War in general (Jakovina, 2011; Lees, 1993). Thus, the strongest impression left by Yugoslav cooperation with FRELIMO is that of solidarity, and the main message of this film is liberation from colonial rule. In his analysis of the work of Stevan Labudović, Turajlić has rightly concluded that the whole Filmske novosti non-aligned project entailed the building of a new narrative centred on solidarity as opposed to otherness (Turajlić, 2017b). It is very possible that, with this policy, Filmske novosti managed to affirm itself in relation not only to various belligerent sides in Africa, but also to various anti-colonial movements in the world, from Sweden and Denmark to the US. And although Filmske novosti, as well as the majority of Yugoslav film producers and distributors, acted largely in accordance with market principles, it gave up ("although reluctantly") the commercial placement of the film, ${ }^{24}$ which was featured in numerous Weeks of Fight against Colonialism whenever and wherever the opportunity presented itself.

The propaganda efforts made by Filmske novosti to promote FRELIMO and other anti-colonialist movements have certainly had an influence on filmmakers around the world. Robert van Lierop's documentary $A$ luta continua is a good example of such influence. Many motifs and scenes from $W e$ Shall Win are also present in this documentary, such as the modernization of the army and weapons, the role of women in the liberation movement, the importance of both military and school education. Lierop's film also alludes to agricultural surpluses and the work of the people of Mozambique as being for their own benefit instead of that of the colonizers. The same applies to other documentaries shot in the liberated areas, such as Margaret Dickinson's Bebind the Lines (1971). At one point in Lierop's film, the very message "We Shall Win" is conveyed, in a sort of reference not only to the Yugoslav documentary, but also to the "Venceremos" guerrilla march that was probably the inspiration for the title of Popović's film. In A luta continua, like in We Shall Win, the Mozambican flag stands out as one of the film's most salient symbols. In both films, traditional songs and dances are shown as part of the national culture and national heritage. The only difference, albeit a great one, is that Lierop's film is essentially socialist in character, with a strong ideological and socialist revolutionary agenda and a strong criticism not only of fascist Portugal (as was the case with the Yugoslav film), but also of NATO and the US.

\footnotetext{
${ }^{24}$ Archives of Yugoslavia, no. 559, Opšti materijali 1968, Elaborati o medunarodnim vezama nekih kulturnib i prosvetnib organizacija i institucija, maj 1968 [General materials 1968, Elaborates on international relations of some cultural and educational organizations and institutions, May 1968].
} 
It is evident that in a time of internationalism and solidarity with the new independent states of Africa and Asia, films also contributed to the anti-colonial struggle. FRELIMO's military strategy enabled it to control substantial regions of Mozambique after the 1974 coup in Portugal, leading to its being recognized as the new government of independent Mozambique on 25 June 1975 (Reno, 2011: 56). A number of films made during the armed struggle were released in 1975 (Gray, 2011: 145). Such was the case with two other documentaries by Popović, Nachingwea and Do Rovuma ao Maputo (From Rovuma to Maputo). After the cinema of liberation, which was essentially documentary in nature, came the first fictional features about the decolonization process, produced in the wake of independence (Schefer, 2013: 300). After the liberation of the country, Filmske novosti made several more important documentaries in Mozambique, and in 1985 Time of the Leopards, a Yugoslav-Mozambican co-production by Zdravko Velimirović, was made. Based on the model of Yugoslav partisan films, Time of the Leopards is a war film about the armed struggle for the liberation of Mozambique, set in the early 1970s. It is a fictional account of the anti-colonial war told from the perspective of the colonized. Gray sees it as a last gesture of film solidarity between African and European Marxist states (Gray, 2011: 155). The narrative of solidarity was also fading away in Yugoslavia on the eve of the country's bloody dissolution, and, because of the collapse of Yugoslavia, this film was rarely shown in cinemas or television. At the end of the Cold War, both Mozambique and Yugoslavia were embroiled in civil war conflicts, and that was the end of Marxist ideology in both countries.

\section{Conclusion}

In the wake of the anti-colonial struggle, Filmske novosti made a significant contribution in capturing the struggle for the liberation of African nations and showing it to the rest of the world, leaving lasting traces not only in Yugoslavia but also in Algeria, Mali, Mozambique, Tanzania and Guinea. In addition, by training the first generation of African cameramen in the countries in which they worked, Filmske novosti contributed to the rise of African documentary films as a specific and original genre and to the birth of a new African cinema. A somewhat surprising result of the research presented here is also that in the midst of the global battle between the two opposing Cold War ideologies, Filmske novosti avoided siding with either camp. Instead, its documentaries about the African struggle for independence focused on anti-colonialism, solidarity and the brotherhood of nations. While this may be read as typical non-aligned, or indeed Yugoslav, 
political ideology, the fact remains that, as tools of propaganda, Yugoslav documentaries did not attempt to deliver any other political message to Yugoslav, African or global audiences. An unexpected result of this Yugoslav strategy was that a new film genre of solidarity was created, which soon became a model for a great number of authors who were documenting other anti-colonial movements and their activities across the globe.

Finally, the question remains of what Yugoslavia gained from this? It seems evident that Yugoslavia was committed to furthering the then emerging and rapidly expanding Third World, aiming to unite it, at least to a certain degree, through the NAM, in which Yugoslavia and President Tito had a very important and prominent role. It can also be said that this message had a great impact on the Yugoslav public, which, in the 1950s and early 1960s, still had to be nudged into fully accepting and supporting the country's foreign policies and, consequently, the Yugoslav political regime itself. But the most important result was probably to further the status of Yugoslavia in the emerging Third World, as a relevant supporter of anti-colonialism and liberation movements worldwide. However, if one reads between the lines, it may be argued that by furthering the country in this manner, the Yugoslav leaders were in fact seeking to create a space for a first-mover advantage in the emerging and rapidly expanding Third World market. While an analysis of Yugoslav economic activities in newly established African and non-African states and in the broader context of Yugoslav foreign policies cannot be carried out within the confines of this paper, it may certainly be said that the We Shall Win project was first and foremost a subtle message of solidarity with the Mozambican liberation movement targeted at a global audience.

\section{Edited by João Paulo Moreira}

\section{References}

Andrade-Watkins, Claire (1995), "Portuguese African Cinema: Historical and Contemporary Perspectives: 1969 to 1993", Research in African Literatures, 26(3), 134-150.

Arnold, Guy (2018), Africa. A Modern History 1945-2015. London: Atlantic Book.

Bamba, Mahomed (2011), “In the Name of 'Cinema Action' and Third World: The Intervention of Foreign Film-makers in Mozambican Cinema in the 1970s and 1980s", Journal of African Cinemas, 3(2), 173-185.

Bogetić, Dragan; Dimić, Ljubodrag (2013), Beogradska konferencija nesvrstanih zemalja 1-6. Septembra 1961: prilog istoriji Tre eg sveta. Beograd: Zavod za udžbenike. 
Carvalho, Jorge Pessoa Santos (2018), “A Jugoslávia nas encruzilhadas do 25 de Abril”. Doctoral thesis in History, Faculdade de Letras da Universidade de Coimbra, Coimbra, Portugal.

Dimi , Natalija (2017), “Achievements and Limitations of Yugoslavia’s Policy in Angola during 1960s and 1970s", Afriche e Orienti, 3, 9-30.

Diop, Mohamed (1980/1981), "Razvoj afri kog filma”, Kultura, 51/52, 26-42.

Ferreira, Carolin Overhoff (2011), "Ambivalent Transnationality: Luso-African Co-productions after Independence (1988-2010)”, Journal of African Cinemas, 3(2), 221-245.

Filmske novosti 1944-2014 (2014). Beograd: Filmske novosti.

Gray, Ros (2011), "Cinema on the Cultural Front: Film Making and the Mozambican Revolution”, Journal of African Cinemas, 3(2), 139-160.

Gray, Ros (2012), “'Haven't You Heard of Internationalism?’ The Socialist Friendships of Mozambican Cinema”, in Lars Kristensen (ed.), Postcommunist Film - Russia, Eastern Europe and World Culture. Moving Images of Postcommunism. London/ /New York: Routledge, 53-74.

Jakovina, Tvrtko (2011), Treća strana Hladnog rata. Zagreb: Fraktura.

Lees, Lorraine M. (1993), Keeping Tito Afloat. The United States, Yugoslavia, and the Cold War. Pennsylvania: Penn State University Press.

Ljubojević, Boško; Bogdanović, Branko (2011), Oružje i vojna oprema: katalog zbirke Istorijskog muzeja Srbije. Beograd: Istorijski muzej Srbije.

Luque, Alba Martin (2017), "International Shaping of a Nationalist Imagery? Robert van Lierop, Eduardo Mondlane and A luta continua”, Afriche e Orienti, 3, 115-138.

Petrović, Petar (ed.) (1981), Vojni leksikon. Belgrade: Vojnoizdavački zavod.

Power, Marcus (2004), "Post-colonial Cinema and the Reconfiguration of Moçambicanidade”, Lusotopie, 11, 261-278. Accessed on 14.11.2018, at https://www.persee.fr/ doc/luso_1257-0273_2004_num_11_1_1605.

Radonjić, Nemanja (2017), "Drums of Revolution: Veda Zagorac and Zdravko Pečar", in Ana Sladojević; Emilia Epštajn (eds.), Nympakorndzidzi: one man, no chop. (Re) conceptualization of the Museum of African Art - The Veda and Dr. Zdravko Pečar Collection. Beograd: The Museum of African Art, 156-175.

Radonjić, Nemanja (n.d.), "Slika Afrike u Jugoslaviji 1945-1991". Manuscript of the Doctoral thesis, Faculty of Philosophy, University of Belgrade, Belgrade, Serbia (work in progress).

Reno, William (2011), Warfare in Independent Africa: New Approaches to African History. New York: Cambridge University Press.

Rothermund, Dietmar (2006), The Routledge Companion to Decolonization. London/ /New York: Routledge.

Rubinstein, Alvin Z. (1970), Yugoslavia and the Nonaligned World. Princeton: Princeton University Press. 
Schefer, Raquel (2013), "Fictions of the Liberation Struggle: Ruy Guerra, José Cardoso, Zdravko Velimirovic”, Kronos: South African Histories, 39, 298-315.

Schneidman, Witney J. (1978), "FRELIMO's Foreign Policy and the Process of Liberation”, Africa Today, 25(1), 57-67.

Sousa, Ana Naomi de (2016), "Between East and West: The Cold War's Legacy in Africa", Al Jazeera, 22 February. Accessed on 08.09.2017, at http://www.aljazeera.com/ indepth/features/2016/02/east-west-cold-war-legacy-africa-160214113015863.html.

Turajlić, Mila (2017a), "Filmske novosti - Filmska diplomatija”, in Marko Jelić (ed.), Alžir-Beograd jubilej prijateljstva 1962-2017: 55 godina nezavisnosti Ažira. Beograd: Društvo prijatelja Alžira, 170-177.

Turajlić, Mila (2017b), "Re-aligning Yugoslavia: The Construction of Alterity in the Yugoslav Newsreels”, On_Culture: The Open Journal for the Study of Culture, 4. Accessed on 15.11.2018, at https://www.on-culture.org/journal/issue-4/turajilicre-aligning-yugoslavia/.

Vučetić, Radina (2017a), "Uspostavljanje jugoslovenske filmske saradnje s Afrikom”, Godišnjak za društvenu istoriju, 2, 57-81.

Vučetić, Radina (2017b), “Tito’s Africa: Representation of Power during Tito’s African Journeys”, in Radina Vučetić; Paul Betts (eds.), Tito in Africa: Picturing Solidarity. Belgrade: Museum of Yugoslavia, 12-45.

Westad, Odd Arne (2005), The Global Cold War. Third World Interventions and the Making of Our Times. Cambridge: Cambridge University Press.

Received on 25.11.2018

Accepted for publication on 21.02.2019

\section{Radina Vučetić}

Faculty of Philosophy, University of Belgrade Čika Ljubina 18-20, 11000 Belgrade, Serbia

Contact: rvucetic@gmail.com

ORCID: https://orcid.org/0000-0001-8035-8480 


\section{We Shall Win (Venceremos): a cooperação cinematográfica jugoslava com a FRELIMO}

Este artigo aborda a cooperação cinematográfica jugoslavo-moçambicana, bem como o papel que Filmske novosti ("Os filmes de atualidade da Jugoslávia") desempenhou na luta anticolonial e na colaboração com o movimento FRELIMO (Frente de Libertação de Moçambique). A cooperação cinematográfica jugoslava com África começou na década de 1950 e atingiu o auge na década de 1960, quando se organizaram as semanas dos filmes jugoslavos nos recém-libertados países africanos e quando Filmske novosti fez os primeiros documentários na Argélia, Mali, Tanzânia, Guiné e Moçambique. A cooperação cinematográfica com Argélia e Moçambique e o apoio aos movimentos guerrilheiros, como a Frente de Libertação Nacional - FLN (Argélia) e a FRELIMO (Moçambique), representaram o auge da solidariedade cinematográfica jugoslava com a luta anticolonial. O filme jugoslavo We Shall Win, de Dragutin Popović, teve um papel particularmente relevante, tendo sido o primeiro documentário sobre as regiões libertadas em Moçambique e o papel militar e político da FRELIMO.

Palavras-chave: anticolonialismo; documentário cinematográfico; FRELIMO; Jugoslávia; Moçambique; movimentos de libertação.

\section{We Shall Win (Nous vaincrons): coopération cinématographique yougoslave avec le FRELIMO}

Cet article est consacré à la coopération entre le cinéma yougoslave et mozambicain et au rôle joué par Filmske novosti ("les films d'actualité yougoslaves") dans la lutte anticoloniale et dans la coopération avec le mouvement FRELIMO (Front de Libération du Mozambique). La coopération cinématographique yougoslave avec l'Afrique a débuté dans les années 1950 et a atteint son apogée dans les années 1960, lorsque les semaines du film yougoslave ont été organisées dans les pays africains nouvellement libérés et Filmske novosti a réalisé ses premiers documentaires en Algérie, au Mali, en Tanzanie, en Guinée et au Mozambique. La coopération cinématographique avec l'Algérie et le Mozambique et le soutien apporté à des mouvements de guérilla tels que le Front de Libération Nationale - FLN (Algérie) et le FRELIMO (Moçambique) ont constitué l'apogée de la solidarité cinématographique yougoslave avec la lutte anticoloniale. Le film yougoslave We Shall Win, de Dragutin Popović, a joué un rôle particulièrement important en tant que premier documentaire sur les régions libérées du Mozambique et sur le rôle militaire et politique de FRELIMO. Mots-clés: anticolonialisme; documentaire cinématographique; FRELIMO; mouvements de libération; Mozambique; Yougoslavie. 
